\title{
PENGARUH HARGA, LOKASI DAN GAYA HIDUP TERHADAP KEPUTUSAN PEMBELIAN RUMAH DI PERUMAHAN MADE GREAT RESIDENCE KOTA LAMONGAN
}

\author{
*( Luluk Nur Azizah, S.Pd, M.Pd \\ Prodi Manajemen, Fakultas Ekonomi, Universitas Islam Lamongan \\ $\mathrm{Jl}$. Veteran No.53A Lamongan \\ Telp. (0322 ) 324706, Faks. (0322) 324706 \\ Email :jpim.unisla@gmail.com
}

\begin{abstract}
ABSTRAK
Pada zaman sekarang ini pertumbuhan penduduk di Indonesia mengalami pertumbuhan yang sangat cepat. Dengan meningkatnya penduduk, maka kebutuhan akan semakin beraneka ragam, salah satunya kebutuhan manusia yang mendasar adalah kebutuhan akan tempat tinggal atau rumah. Masalah tempat tinggal masih menjadi polemik, seperti permasalahan yang dihadapi oleh penduduk di perkotaan adalah kurangnya lahan perumahan yang mengakibatkan harga rumah atau tanah sangat tinggi dan sulit didapatkan. Penelitian ini bertujuan menguji dan menganalisis pengaruh harga, lokasi dan gaya hidup secara parsial dan simultan terhadap keputusan pembelian rumah di Perumahan Made Great Residence di Kota Lamongan. Pendekatan penelitian yang digunakan dalam penelitian ini merupakan pendekatan kuantitatif. Populasi dalam penelitian ini adalah konsumen yang telah membeli rumah di Perumahan Made Great Residence di Kota Lamongan 100 orang. Metode pengambilan sampel adalah proporsional sampling. Sampel dalam penelitian ini sebanyak 50 orang / responden. Variabel bebas penelitian ini adalah harga $\left(X_{1}\right)$, lokasi $\left(X_{2}\right)$, gaya hidup $\left(X_{3}\right)$ dan keputusan pembelian $(Y)$ sebagai variabel terikat. Uji instrumen dengan menggunakan uji validitas dan reliabilitas. Metode analisis yang digunakan adalah analisis regresi linier berganda, dengan mempertimbangkan syarat uji asumsi klasik yaitu uji normalitas, uji multikolinieritas, uji autokorelasi dan uji heteroskedastisitas. Pengujian hipotesis yang digunakan adalah uji statistik secara parsial (uji t) dan uji statistik secara simultan (uji F) dengan taraf signifikan $\alpha=5 \%$. Penganalisan data menggunakan program SPSS for windows versi 20. Hasil pengujian secara secara parsial menunjukkan variabel harga, lokasi dan gaya hidup memberikan pengaruh signifikan dan positif terhadap keputusan pembelian. Sedangkan hasil pengujian simultan menunjukkan seтиa variabel berpengaruh terhadap keputusan pembelian rumah di Perumahan Made Great Residence di Kota Lamongan.
\end{abstract}

Kata Kunci: Harga, Lokasi, Gaya Hidup, dan Keputusan Pembelian

\section{PENDAHULUAN}

\section{Latar Belakang}

Pada zaman sekarang ini pertumbuhan penduduk di Indonesia mengalami pertumbuhan yang sangat cepat. Diperkirakan selama dua puluh tahun mendatang dari 252.164,80 ribu jiwa pada tahun 2014 menjadi 303.996,70 ribu jiwa pada tahun 2034 (www.bps.go.id), demikian pula pertumbuhan ekonomi di Indonesia yang juga meningkat, tercatat tumbuh $5,14 \%$ pada tahun 2014. Namun masalah tempat tinggal masih menjadi polemik. Permasalahan tempat tinggal yang dihadapi oleh penduduk yang tinggal di daerah pedesaan pada umumnya adalah lemahnya kemampuan ekonomi serta kurangnya pendidikan dan pengetahuan tentang bagaimana membangun rumah yang sehat dan layak. Sedangkan 
permasalahan yang dihadapi oleh penduduk di perkotaan adalah kurangnya lahan perumahan di kota yang mengakibatkan harga rumah atau tanah sangat tinggi dan sulit didapatkan.

$$
\text { Menurut Kotler }
$$

seseorang dalam melakukan pengambilan keputusan untuk membeli tidak secara langsung dapat dilakukan, namun harus melalui beberapa proses yang disebut dengan buyer decision process, yaitu suatu proses yang harus dilakukan oleh seseorang sebelum memutuskan untuk membeli rumah

Namun, tidak semua masyarakat bisa dengan mudah membangun rumah. Diperlukan berbagai hal, sehingga rumah bisa didirikan dan ditempati, Maka tidak mengherankan jika akhir-akhir ini bisnis di bidang perumahan semakin marak, banyak perusahaan muncul dengan memberikan berbagai macam fasilitas dan perkembangan bisnis ini sudah tidak hanya terpusat di kota-kota besar akan tetapi sudah meluas di kota-kota kecil.

PT. Caranggana Dasa Perkasa merupakan salah satu pengembang perumahan yang menyediakan rumah dengan berbagai

tipe. Pemasaran perumahan pada umumnya memiliki atribut penawaran yang hampir sama. PT Caranggana Dasa Perkasa mencoba memberikan penawaran perumahan yang diberi nama Perumahan Made Great Residence dimana perumahan ini memiliki keunggulan yaitu lokasi yang strategis aksesnya mudah, nyaman, bebas polusi serta kawasan dengan sistem satu pintu akses keluar masuk.

Berdasarkan uraian penjelasan di atas, maka dirasakan perlu untuk membahas lebih lanjut mengenai

\section{"Pengaruh Harga, Lokasi, dan Gaya Hidup terhadap Keputusan Pembelian Rumah di Perumahan Made Great Residence di kota Lamongan".}

\section{Identifikasi Masalah}

Berdasarkan latar belakang masalah tersebut, maka dapat diidentifikasi sebagai berikut :

a. Kesejahteraan masyarakat yang meningkat menyebabkan kebutuhan masyarakat juga meningkat, salah satunya kebutuhan akan perumahan atau pemukiman.

b. Setiap manusia membutuhkan rumah untuk berlindung akan tetapi tidak semua masyarakat bisa dengan mudah membangun rumah, masih diperlukan berbagai hal sehingga rumah itu bisa didirikan dan ditempati.

c. Perkembangan bisnis perumahan semakin marak sehingga menyebabkan masyarakat menempuh cara yang lebih efektif dan tidak menyita banyak waktu.

d. Adanya pengaruh faktor psikologis yang ada pada diri konsumen seperti gaya hidup terhadap keputusan pembelian.

\section{Rumusan Masalah}

a. Apakah terdapat pengaruh harga terhadap keputusan pembelian rumah di Perumahan Made Great Residence di kota Lamongan?

b. Apakah terdapat pengaruh lokasi terhadap keputusan pembelian rumah di Perumahan Made Great Residence di kota Lamongan?

c. Apakah terdapat pengaruh gaya hidup terhadap keputusan pembelian rumah di Perumahan Made Great Residence di kota Lamongan?

d. Apakah terdapat pengaruh harga, lokasi dan gaya hidup terhadap keputusan pembelian rumah di Perumahan Made Great Residence di kota Lamongan?

\section{Tujuan Penelitian}

Tujuan yang ingin dicapai dalam penelitian ini adalah sebagai berikut:

a. Untuk mengetahui pengaruh harga terhadap keputusan pembelian rumah di Perumahan Made Great Residence di kota Lamongan

b. Untuk mengetahui pengaruh lokasi terhadap keputusan pembelian rumah di Perumahan Made Great Residence 
di kota Lamongan

c. Untuk mengetahui pengaruh gaya hidup terhadap keputusan pembelian rumah di Perumahan Made Great Residence di kota Lamongan.

Untuk mengetahui pengaruh harga, lokasi dan gaya hidup secara simultan terhadap keputusan pembelian rumah di Perumahan Made Great Residence di kota Lamongan.

\section{KAJIAN PUSTAKA}

\section{Keputusan Pembelian}

Menurut Kotler (2005:202) keputusan pembelian adalah "Karakteristik pembeli dan proses pengambilan keputusannya akan menimbulkan keputusan pembelian". Sedangkan menurut (Setiadi, 2003:11) "keputusan pembelian seseorang merupakan hasil yang saling berhubungan, saling mempengaruhi antara faktor-faktor budaya, sosial, pribadi dan psikologi". Indikator keputusan pembelian menurut Kotler (2005:204) adalah : pengenalan masalah, pencarian informasi, evaluasi alternatif, keputusan pembelian, dan perilaku pasca pembelian.

\section{Harga}

Menurut Swastha dan Irawan (2008 : 241) harga adalah "jumlah uang (ditambah Beberapa barang kalau mungkin) yang dibutuhkan untuk mendapatkan sejumlah kombinasi dari barang beserta pelayanannya". Sedangkan menurut (Kotler dan Amstrong, 2001:466) harga adalah "sejumlah uang yang ditukarkan untuk sebuah produk atau jasa". Indikator harga menurut Hermann, et. al. (2007:54) adalah keterjangkauan harga, diskon/potongan harga, dan cara pembayaran.

\section{Lokasi}

Menurut Swasta dan Irawan (2003:339) "Lokasi adalah letak pada daerah yang strategis sehingga dapat memaksimumkan laba" Sedangkan menurut ( Lupiyoadi, 2001 : 61 - 62 ) mendefinisikan "lokasi adalah tempat di mana perusahaan harus bermarkas melakukan operasi”. Indikator dalam menentukan lokasi menurut Tjiptono (2000:41-42) meliputi akses, visibilitas, tempat parkir, ekspansi, dan lingkungan.

\section{Gaya Hidup}

Menurut Enggel, Blackwell dan Miniard dalam Sumarwan (2003:56), "gaya hidup adalah sebagai pola dimana orang hidup dan menggunakan uang dan waktunya" Sedangkan menurut Solomon dalam Sumarwan (2003:56) mendefinisikan bahwa "gaya hidup adalah cerminan pola konsumsi yang menggambarkan pilihan seseorang bagaimana ia menggunakan waktu dan uangnya",Adapun indikator gaya hidup menurut Kotler (2005:204) adalah : aktivitas,dan minat

\section{Kerangka Berpikir}

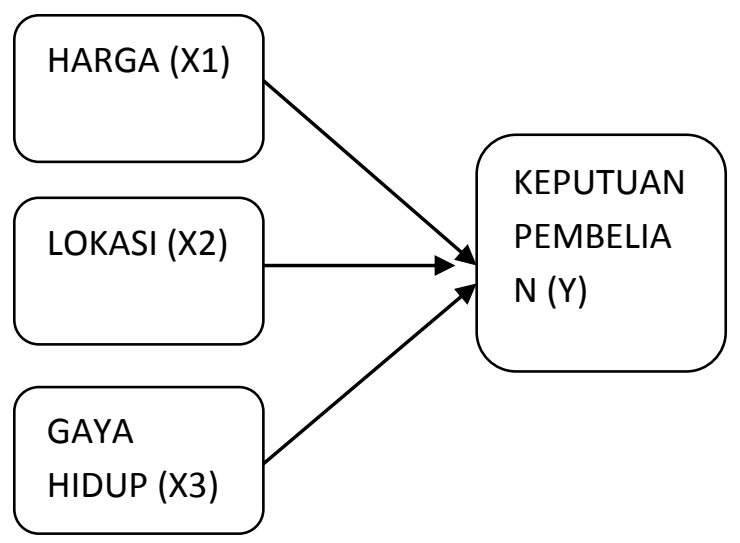

Gambar 1. Kerangka Konseptual

\section{Hipotesis}

H1 : Harga secara parsial berpengaruh signifikan terhada keputusan pembelian rumah pada Perumahan Made Great Residence.

$\mathrm{H}_{2}$ : Lokasi secara parsial berpengaruh signifikan terhadap keputusan pembelian rumah pada Perumahan Made Great Residence.

H3 : Promosi secara parsial berpengaruh signifikan terhadap keputusan pembelian rumah pada Perumahan Made Great 
Residence

H4 : Harga, lokasi, dan gaya hidup berpengaruh terhadap keputusan pembelian rumah pada Perumahan Made Great Residence

\section{METODE PENELITIAN}

\section{Teknik dan Pendekatan Penelitian}

Penelitian ini merupakan penelitian eksplanatori, yaitu penelitian yang bertujuan untuk menguji suatu teori atau hipotesis antar variabel yang telah dirumuskan sebelumnya. Sedangkan Pendekatan dalam penelitian ini adalah pendekatan kuantitatif, karena penelitian ini disajikan dengan angka-angka.

\section{Tempat dan Waktu Penelitian}

Penelitian ini dilakuka di PT. Caranggana Dasa Perkasa dan di lokasi proyek perumahan Made Great Residence yang terletak di Jl. Mastrip desa made kec lamongan kab lamongan. Waktu peneliti dilakukan selama 4bulan terhitung mulai bulan april sampai dengan Juni 2015.

\section{Populasi dan Sampel}

Populasi dalam penelitian ini adalah jumlah konsumen yang telah membeli rumah di Perumahan Made Great Residence dari tahun 2010 sampai 2015, yaitu sebanyak 100unit rumah yang dihuni. Sedangkan sampel yang digunakan sebanyak 50 responden. Penentuan sampel dalam penelitian ini menggunakan proporsional sampling. Menurut Sugiyono (2003:76) Proporsional sampling adalah pengambilan sampel yang memperhatikan pertimbangan unsur-unsur atau kategori dalam populasi penelitian.

\section{HASIL PENELITIAN DAN PEMBAHASAN}

\section{Karakteristik Responden}

Adapun jumlah responden yang telah ditetapkan sebanyak 50 responden penghuni perumahan Made Great Residence, dengan teknik Proporsional Sampling. Karakteristik responden yang menjadi subjek dalam penelitian ini terdiri dari jenis kelamin, usia, tingkat pendidikan, tingkat pendapatan.

\section{Uji Instrumen}

1. Uji Validitas

nilai dari hasil uji $\mathrm{r}$ hitung > r tabel, dan berdasrkan nilai sig. $0,000<$ 0,05 , sehingga dapat disimpulkan bahwa semua item pertanyaan dalam kuisioner adalah valid.

2. Uji Reliabilitas

nilai alpha cronbach untuk harga adalah 0.824 , lokasi 0.773 , gaya hidup 0.883, dan keputusan pembelian 0.810 , terbukti lebih besar daripada alpha kritis yaitu 0.6. Hal ini berarti bahwa pernyataan untuk seluruh item pernyataan adalah baik bagi variabel harga, lokasi, promosi, gaya hidup serta keputusan pembelian.

\section{Analisis Data}

\section{Uji Asumsi Klasik}

a. Uji Normalitas

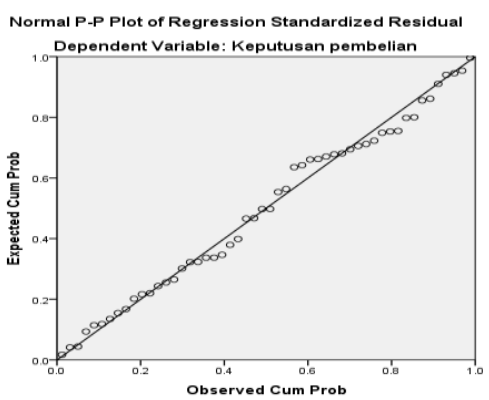

(sumber diolah SPSS tahun 2015) 


\section{Analisis Regresi Linear Berganda}

Berdasarkan hasil analisis, maka dapat dibuat persamaan regresi linier berganda sebagai berikut:

$$
\begin{aligned}
& Y=\beta 0+\beta 1 . X_{1}+\beta_{2} \cdot X_{2}+\beta 3 . X_{3}+e \\
& =1,236+0,296 \mathrm{X} 1+0,204 \mathrm{X} 2+ \\
& 0,258 \mathrm{X} 4
\end{aligned}
$$

\section{Koefisien Determinasi}

\begin{tabular}{|l|l|l|l|l|}
\hline Model & $\mathrm{R}$ & $\begin{array}{l}\text { Squar } \\
\mathrm{e}\end{array}$ & $\begin{array}{l}\text { Adjuste } \\
\mathrm{d} \\
\mathrm{R}\end{array}$ & $\begin{array}{l}\text { Std. Error } \\
\text { of the } \\
\text { Estimate }\end{array}$ \\
\hline 1 & $940^{\mathrm{a}}$ & .884 & .874 & 1.577 \\
\hline
\end{tabular}

(sumber diolah SPSS tahun 2015)

\section{Uji Hipotesis}

a. Uji t

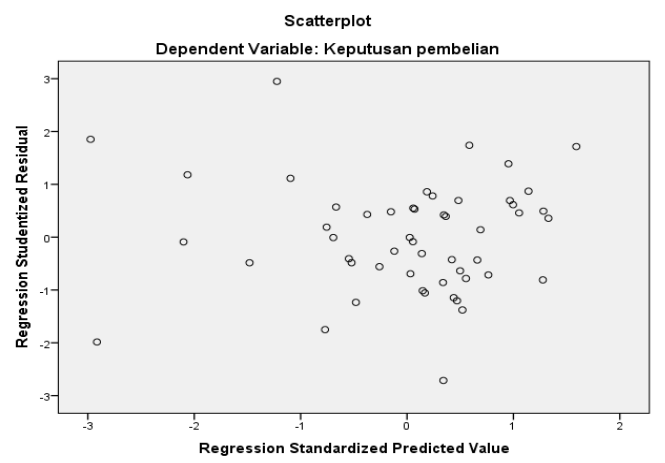

(sumber diolah SPSS tahun 2015)

b. Uji F

\section{KESIMPULAN \\ Kesimpulan}

Berdasarkan hasil dan pembahasan maka dapat diambil kesimpulan sebagai

berikut:

1. Ada pengaruh positif dan signifikan antara harga terhadap keputusan rumah pada Perumahan Made Great Residence.

2. Ada pengaruh positif dan signifikan antara lokasi terhadap keputusan pembelian rumah pada Perumahan Made Great Residence

3. Ada pengaruh positif dan signifikan antara gaya hidup terhadap keputusan pembelian rumah pada Perumahan Made Great Residence

4. Ada pengaruh positif dan signifikan antara harga, lokasi gaya hidup terhadap keputusan pembelian rumah pada Perumahan Made Great Residence.

\section{Saran}

Adapun saran yang dapat peneliti berikan dalam penelitian ini adalah sebagai berikut:

1.Bagi perusahaan

Diharapkan dengan adanya penelitian ini, PT. Caranggana dasa perkasa selaku developer dan kontraktor terus melakukan evaluasi terhadap perusahaannya. Menetapkan harga jual yang disesuaikan dengan

\begin{tabular}{|l|r|r|r|r|r|}
\hline Model & $\begin{array}{c}\text { Sum of } \\
\text { Squares }\end{array}$ & Df & $\begin{array}{c}\text { Mean } \\
\text { Square }\end{array}$ & F & Sig. \\
\hline $\begin{array}{c}1 \text { Regres } \\
\text { sion }\end{array}$ & 889.633 & 4 & 222.408 & 89.431 & $.000^{\mathrm{b}}$ \\
$\begin{array}{l}\text { Residu } \\
\text { al }\end{array}$ & 116.886 & 4 & 2.487 & & \\
Total & 1006.519 & 5 & & & \\
\hline
\end{tabular}

qualitas produk dan lebih banyak nemberikan diskon, pemilihan lokasi ang strategis yang bisa di akses engan armada transportasi umum gengan mudah, mengetahui perubahan gaya hidup yang ada di pasyarakat sehingga dapat menawarkan roduk sesuai dengan kehidupan ehingga akan manarik minat konsumen untuk membeli.

a. Dependent Variable:

Keputusanpembelian

b. Predictors: (Constant), Gaya hidup, Lokasi, Harga

(sumber diolah SPSS tahun 2015)
2. Bagi peneliti selanjutnya.

Hasil penelitian ini dapat dijadikan jembatan untuk melakukan penelitian lanjutan khususnya dibidang kajian yang sama.Untuk 
penelitian selanjutnya, sebaiknya memperluas variabel penelitian sehingga dapat menghasilkan penelitian yang lebih akurat. Hal ini diusulkan karena telah terbukti bahwa variabel harga, lokasi dan gaya hidup berpengaruh terhadap keputusan pembelian sebesar $87,4 \%$ yang artinya masih ada $12,6 \%$ dipengaruhi oleh faktor lain.

\section{DAFTAR PUSTAKA}

Arikunto, Suharsini. 2006.Prosedur

Penelitian : Suatu pendekatan

Praktik. Jakarta: Asdi mahasatya.

Arikunto, S. 2010. Prosedur Penelitian

Suatu pendekatan praktik. Jakarta:

PT. Rineka Cipta

Basu, Swastha dan Irawan, 2003. Manajemen Pemasaran Modern. Yogyakarta : Liberty

Kotler, philip, 2005, Manajemen

Pemasaran, jilid 1 \& 2, Jakarta:

PT. Indeks Kelompok Gramedia

Kotler, Philip. 2007. Manajemen

Pemasaran, Analisis Perencanaan,

Pengendalian, Prentice Hall,

Edisi Bahasa Indonesia, Jakarta:

Salemba Empat Lupiyoadi,

Hamdani. 2001. Manajemen

Pemasaran Jasa :Teori dan

Praktek, Edisi Pertama, Jakarta:

Penerbit Salemba Empat. 